\title{
MEDIA PEMBELAJARAN BERBANTUAN 3D PAGEFLIP PROFESSIONAL MATERI NILAI MUTLAK
}

\section{LEARNING MEDIA ASSISTED 3D PAGEFLIP PROFESSIONAL IN ABSOLUTE VALUE MATERIAL}

\author{
Ade Marganda ${ }^{a}$, Netriwati ${ }^{\mathrm{b}}$, Siska Andrianic \\ aProgram Studi Pendidikan Matematika UIN Raden Intan Lampung \\ Jl. Letkol H. Endro Suratmin Sukarame Bandar Lampung Telp. (0721)703260 \\ ademarganda1@gmail.com \\ bProgram Studi Pendidikan Matematika UIN Raden Intan Lampung \\ Jl. Letkol H. Endro Suratmin Sukarame Bandar Lampung Telp. (0721)703260 \\ netriwati@gmail.com \\ 'Program Studi Pendidikan Matematika UIN Raden Intan Lampung \\ Jl. Letkol H. Endro Suratmin Sukarame Bandar Lampung Telp. (0721)703260 \\ siskaandriani@radenintan.co.id
}

\begin{abstract}
ABSTRAK
Penelitian ini bertujuan untuk menghasilkan bahan ajar berupa E-Modul pada mata kuliah analisis real materi nilai mutlak dengan menggunakan $e$-modul dapat memperoleh informasi tanpa banyak membuang waktu dan bisa dibawa kemana-mana agar tercapai pembelajaran yang efektif dan menarik. Metode penelitian ini adalah Research and Development (R\&D) berdasarkan model ADDIE yang terdiri dari lima tahapan, yaitu Analysis, Design, Development, Implementation, and Evaluation. Subyek penelitian ini adalah mahasiswa jurusan pendidikan matematika UIN Raden Intan Lampung. Data penelitian diperoleh dengan teknik wawancara, angket, dan tes. Hasil penilaian berdasarkan angket validasi ahli materi terhadap e-modul ini termasuk dalam kategori valid dengan nilai rata-rata sebesar 3,52 dari rata-rata skor tertinggi 4.00. Penilaian ahli media terhadap $e$-modul ini termasuk dalam kategori valid dengan nilai rata-rata sebesar 3,50. Pada uji coba skala kecil yang diikuti oleh 10 mahasiswa memperoleh skor rata-rata 3,46 dari skor tertinggi dengan rata-rata 4.00 berdasarkan hasil dari angket respon yang telah diisi oleh mahasiswa, hasil ini menempatkan e-modul pada kriteria sangat menarik. Pada uji coba lapangan skala besar yang diikuti oleh 30 mahasiswa skor rata-rata kemenarikan yang diperoleh yaitu 3,51 sangat menarik. Kualitas keefektifan produk dilihat dari tes hasil belajar. Hasil penelitian dan pengolahan data menggunakan uji effect size dengan hasil 0,71 dengan kriteria sedang. Berdasarkan hasil tersebut dapat disimpulkan bahwa e-modul berbantuan software 3D PageFlip Professional pada mata kuliah analisis real materi nilai mutlak layak dan efektif untuk dijadikan alat bantu pembelajaran.
\end{abstract}

Kata Kunci : Analisis Real, Nilai Mutlak, Software 3D PageFlip Professional

\section{ABSTRACT}

This study aims to produce teaching materials in the form of E-Modules in real material analysis courses of absolute value by using e-modules to obtain information without wasting much time and can be carried everywhere in order to achieve effective and interesting learning. This research 
method is Research and Development (R\&D) based on the ADDIE model which consists of five stages, namely Analysis, Design, Development, Implementation, and Evaluation. The subjects of this study were students majoring in mathematics education at UIN Raden Intan Lampung. The research data were obtained by interview, questionnaire, and test techniques. The assessment results are based on a material expert validation questionnaire for this e-module included in the valid category with an average value of 3.52 from the highest average score of 4.00. Media expert's assessment of this e-module is included in the valid category with an average value of 3.50. In the small-scale trial that was followed by 10 students, they got an average score of 3.46 from the highest score with an average of 4.00 based on the results of the questionnaire responses that have been filled out by students, this result places the e-module on very interesting criteria. In the large-scale field trial which was attended by 30 students the average score of attractiveness obtained which was 3.51 was very interesting. The quality of the effectiveness of the product can be seen from the test of learning outcomes. The results of research and data processing using the effect size test with the results of 0.71 with moderate criteria. Based on these results it can be concluded that the e-module assisted by 3D PageFlip Professional software in real material analysis courses is absolutely feasible and effective value to be used as a learning aid.

Keywords: Real Analysis, Absolute Value, 3D PageFlip Professional Software

\section{Pendahuluan}

Kemajuan Teknologi Informasi dan Komunikasi (TIK) di indonesia berkembangan sangat pesat. Salah satu teknologi yang saat ini sedang berkembang dan cukup banyak diminati oleh masyarakat ialah komputer (Titon Agung Saputro, Kriswandani, dan Novisita Ratu, 2018). Kemajuan ilmu pengetahuan dan teknologi pada saat ini tidak lepas dari peran pendidikan, dan pendidikan merupakan bagian hakiki dari kehidupan masyarakat (Ainul Yaqin, dan Rochmawati, 2017). Menurut Pujiriyanto (2012) pekembangan teknologi sangat mempengaruhi perkembangan proses pembelajaran terutama dalam sistem penyampaian melalui pemanfaatan media generasi baru. Proses pendidikan tidak dapat dipisahkan dari proses pembelajaran (Shanley, 2016).

Berkembangnya ilmu, teknologi dan informasi membawa perubahan dan paradigma baru pada learning material dan learning method (Darmawan, 2012). Produk dari teknologi dan informasi telah memberikan alternatif bahan ajar yang dapat digunakan dan diakses peserta didik dalam bentuk digital seperti e-modul (Zainal Abidin, dan Sikky El Walida, 2017). E-modul adalah salah satu media yang efektif, efisien, dan mengutamakan kemandirian peserta didik. Banyak sekali aplikasi teknologi dan informasi yang dapat dijadikan $e$ modul salah satunya aplikasi 3D PageFlip.

$$
\text { Software 3D PageFlip }
$$

Professional adalah "asoftware that 
convert your still PDF files into animated 3D page turningbooks which include a multimedia music and videos on pages, links, images, button, and animation to become a 3D Flip Book". Berdasarkan pendapat tersebut, dapat diketahui bahwasannya 3D Flip Book yaitu sebuah software untuk merubah file format PDF menjadi animasi buku 3D yang dapat dimasukkan video, musik, tombol, gambar dan animasi (Kurniawati, 2016).

Beberapa penjelasan diatas peneliti akan melakukan pengembangan e-modul sebagai media pembelajaranyang menggunakan 3D PageFlip Professional. Namun, sebelum itu peneliti melakukan prasurvey wawancara terhadap salah satu dosen pendidikan matematika di UIN Raden Intan Lampung, dan STKIP PGRI Bandar Lampung. Hasil wawancara menyimpulkan bahwa khususnya pada mata kuliah analisis real masih sangat kurang media pendukung pembelajaran. Selama beliau mengajar beliau memanfatkan buku pegangan untuk mengajar didalam kelas dan pemanfaatan teknologi yang digunakan fasilitasi proyektor namun hanya sebatas menampilkan power point saja.
Peneliti memperoleh sumber referensi dari penelitian terlebih dahulu sebagai acuan untuk penelitian ini. Menurut Taufik Solihudin JH (2018) penelitiannya terhadap pengembangan emodul berbasis web dapat digunakan sebagai multimedia pembelajaran dan dapat meningkatkan pencapaian kompetensi pengetahuan peserta didik. E-modul berbasis LCDS yang dikombinasi dengan software I-Spring mendapatkan kriteria "Sangat menarik" dan sangat layak untuk digunakan (Iin Rahmatul Ula, dan Abi Fadila, 2018). Sedangkan menurut Asro Nur Aini, Bambang Sri Anggoro, dan Fredi Ganda Putra (2018) pengembangan media pembelajaran matematika dinyatakan layak dan menarik digunakan pada mahasiswa berdasarkan hasil angket respon ketertarikan.

\section{Metode Penelitian}

Penelitian ini menggunakan model penelitian dan pengembangan (research and development). Research and development merupakan metode penelitian untuk menghasilkan produk tertentu, dan menguji keefektifan produk tersebut atau sering disingkat menjadi $R \& D$ (Mohammad Ali and Muhammad Asrori, 2014 : 105). Produk yang dikembangkan dalam penelitian ini yaitu 
perangkat pembelajaran berupa $e$-modul dengan berbantuan software 3D Pageflip Professional pada materi nilai mutlak. Dalam penelitian ini menggunakan model pengembangan ADDIE (Analysis, Design, Development, Implementation, Evaluation). Dari hasil pertimbangan peneliti pemilihan model penelitian ini lebih sistematis dan lengkap, hal tersebut karena tahap evaluasi terdapat dalam setiap tahapan. Berikut adalah gambar bagan pengembangan model ADDIE.

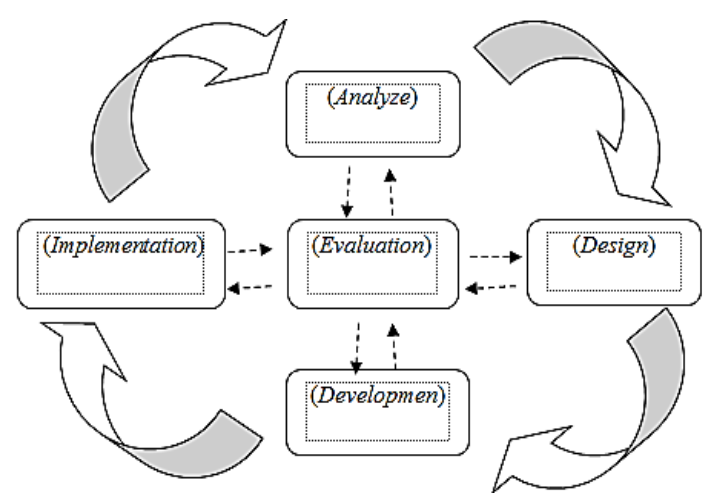

Gambar 1. Bagan Model ADDIE

Subyek penelitian ini adalah mahasiswa jurusan pendidikan matematika UIN Raden Intan Lampung.
Teknik pengumpulan data yang digunakan peneliti adalah wawancara, penyebaran angket dan tes. Angket yang digunakan adalah angket validasi kepada para pakar ahli dan angket mahasiswa. Adapun data kualitatif dihasilkan dari saran dan masukan para pakar ahli sedangkan data kuantitatif dihasilkan dari hasil validasi dan tes yang telah

$$
d=\frac{\text { Mposttest }- \text { Mpretest }}{\sqrt{\frac{S D^{2} \text { posttest }+S D^{2} \text { pretest }}{2}}}
$$

Keterangan:

$\mathrm{M}=$ Rata-rata skor test

$\mathrm{SD}=$ Standar deviasi skor test

Kriteria besar kecilnya effect size diklasifikasikan sebagai berikut :

Tabel 1. Kategori Effect Size

\begin{tabular}{cl}
\hline Effect Size $(\boldsymbol{d})$ & Kategori \\
\hline $0,8 \leq \mathrm{d} \leq 2,0$ & Tinggi \\
\hline $0,5 \leq \mathrm{d}<0,8$ & Sedang \\
\hline $0,2 \leq \mathrm{d}<0,5$ & Rendah
\end{tabular}

\section{Hasil dan Pembahasan}

Penelitian pengembangan ini menghasilkan produk perangkat pembelajaran matematika berupa $E$ Modul pada materi nilai mutlak mata kuliah analisis real. Pengembangan perangkat pembelajaran berupa $e$ - 
modul dilakukan melalui tahap analysis (analisis), design (perancangan), development (pengembangan), implementation (implementasi), evaluation (evaluasi). Adapun penjelasan dari tiap-tiap tahap yang dilalui yaitu sebagai berikut.

1. Tahap Analysis (Analisis)

Tahap analisis pada penelitian ini meliputi analisis kebutuhan, dan analisis karakteristik mahasiswa. Pada analisis kebutuhan peneliti melakukan prasurvei yang menghasilkan bahwa dosen masih menggunakan media pembelajaran berupa buku cetak dari penerbit sebagai sumber belajar. Selain itu, pembelajaran berbantuan buku paket tebal membuat mahasiswa kurang tertarik untuk belajar. Sedangkan analisis karakteristik mahasiswa, peneliti akan menyesuaikan isi $e$ modul sesuai dengan karakteristik mahasiswa antara lain kemampuan akademik individu, fisik, motivasi belajar, latar belakang ekonomi dan social, pengalaman belajar sebelumnya, dsb.

2. Tahap Design (Perancangan)

Tahap perancangan yang dilakukan peneliti meliputi penyusunan kerangka e-modul, perancangan penyajian materi dan perancangan instrumen. Hasil yang diperoleh dari penyusunan kerangka $e$-modul bagian awal (cover) yang berisi tulisan "Nilai Mutlak Analisis Real" dan kata pengantar, bagian isi e-modul berisi tujuan yang harus dicapai, kemudian dilanjutkan materi Nilai Mutlak dan bagian penutup berisi referensi dan biografi. Perancangan penyajian materi yaitu pembuatan e-modul Materi diambil dari buku paket yang digunakan dosen dan dari sumbersumber yang terpercaya. Sedangkan perancangan instrumen peneliti merancang angket berdasarkan aspek yang sudah disesuaikan yang dijadikan angket validasi para ahli serta angket respon mahasiswa untuk memberikan penilaian terhadap $e$ modul.

3. Tahap Development (Pengembangan) Hasil dari tahap perancangan yang telah dilakukan peneliti selanjutnya $e$ modul dibuat secara utuh pada tahap pengembangan yang akan dilakukan validasi untuk memperoleh e-modul yang layak digunakan untuk proses pembelajaran. Berikut gambar hasil awal $e$-modul sebelum validasi. 


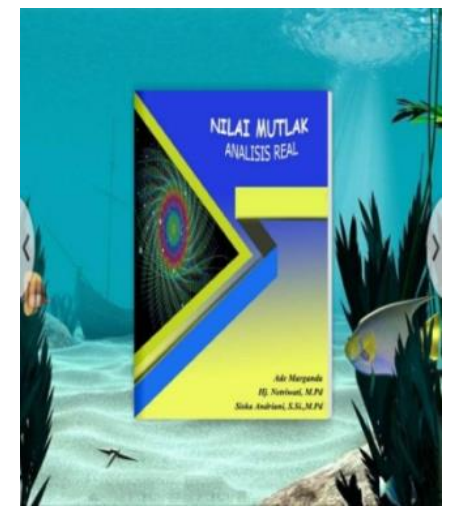

Gambar 1. Bagian Pembuka

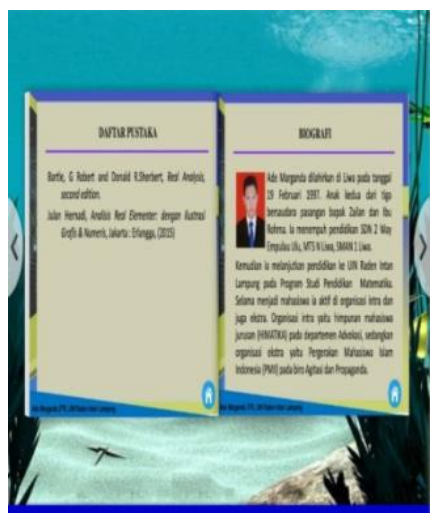

Gambar 2. Bagian Penutup

Peneliti telah selesai membuat $e$ modul selanjutkan divalidasi oleh para ahli media dan ahli materi yang masingmasing terdiri dari tiga validator. Hasil yang diperoleh dari penilaian oleh ahli materi pada aspek kesesuaian materi, keakuratan materi, mendorong keingintahuan, teknik penyajian dan bahasa dapat dilihat pada tabel berikut.
Tabel 2. Hasil validasi tahap 1 oleh ahli materi

\begin{tabular}{lcc}
\hline \multicolumn{1}{c}{ Aspek } & Skor & Keterangan \\
\hline Kesesuaian materi & 3,17 & Cukup Valid \\
\hline Keakuratan materi & 3,2 & Cukup Valid \\
\hline $\begin{array}{l}\text { Mendorong } \\
\text { keingintahuan }\end{array}$ & 3,16 & Cukup Valid \\
\hline Teknik penyajian & 3,33 & Valid \\
\hline Bahasa & 3 & Cukup Valid \\
\hline
\end{tabular}

Penilaian oleh ahli media pada aspek efisiensi media, fungsi tombol, dan grafis dapat dilihat pada tabel berikut.

Tabel 3. Hasil validasi tahap 1 oleh ahli media

\begin{tabular}{lcl}
\hline \multicolumn{1}{c}{ Aspek } & Skor & Keterangan \\
\hline Efesiensi media & 3,08 & Cukup Valid \\
\hline Fungsi tombol & 2,83 & Cukup Valid \\
\hline Grafis & 2,67 & Cukup Valid \\
\hline
\end{tabular}

Berdasarkan hasil validasi tahap 1 yang tertera pada tabel 2 dan 3 oleh ahli materi dan ahli media terdapat skor rata-rata pada kriteria cukup valid. Hal ini berarti e-modul belum layak untuk digunakan dan dilakukan uji coba lapangan. Sehingga $e-m o d u l$ diperbaiki kembali, perbaikan dilakukan sesuai dengan masukan dan saran para ahli.

e-modul selesai dilakukan perbaikan yang sesuai dengan masukan dan saran para ahli. Selanjutnya e-modul divalidasi kembali oleh para ahli. Hasil validasi tahap 2 dapat dilihat pada tabel 3 dan table 4. 
Tabel 4. Hasil validasi tahap 2 oleh ahli materi

\begin{tabular}{lcc}
\hline \multicolumn{1}{c}{ Aspek } & Skor & Keterangan \\
\hline Kesesuaian materi & 3,67 & Valid \\
\hline Keakuratan materi & 3,47 & Valid \\
\hline $\begin{array}{l}\text { Mendorong } \\
\text { keingintahuan }\end{array}$ & 3,83 & Valid \\
\hline Teknik penyajian & 3,67 & Valid \\
\hline Bahasa & 3,33 & Valid \\
\hline
\end{tabular}

Tabel 5. Hasil validasi tahap 2 oleh ahli

\begin{tabular}{lcc}
\multicolumn{3}{c}{ media } \\
\hline Aspek & Skor & Keterangan \\
\hline Efesiensi media & 3,58 & Valid \\
\hline Fungsi tombol & 3,33 & Valid \\
\hline Grafis & 3,61 & Valid \\
\hline
\end{tabular}

Berdasarkan hasil validasi kedua, hasil validasi diperoleh skor rata-rata pada kriteria valid, sehingga disimpulkan e-modul sudah layak digunakan sebagai bahan ajar dan dapat dilakukan uji coba lapangan.

\section{Tahap Implementasi}

Uji coba kemenarikan dan keefektifan produk di lakukan pada tahap implementasi dengan memberikan angket respon dan tes yaitu pretest dan posttest kepada mahasiswa pendidikan matematika UIN Raden Intan Lampung.

Uji kemenarikan produk $e$-modul ini dilakukan pada uji coba skala kecil dan uji coba skala besar. Skala Kecil dilakukan di kelas dengan 10 responden. Hasil uji coba skala kecil diperoleh ratarata nilai 3,46 pada kriteria "Sangat
Menarik". Selanjutnya pada uji coba skala besar dengan melibatkan 30 responden untuk mengetahui kemenarikan e-modul secara luas. Hasil analisis data uji skala besar yaitu 3,51 pada kriteria "Sangat Menarik".

$$
\text { Setelah dilakukan uji }
$$

kemenarikan, mahasiswa diberikan tes berupa pretest dan posttest. Berikut ini tabel hasil perhitungan pretest dan posttest yang peneliti lakukan.

Tabel 6. Data Hasil Perhitungan Pretest dan Posttest

\begin{tabular}{ccccc}
\hline & $N$ & $\begin{array}{c}\text { Skor } \\
\text { Min }\end{array}$ & $\begin{array}{c}\text { Skor } \\
\text { Max }\end{array}$ & $\begin{array}{l}\text { Rata- } \\
\text { Rata }\end{array}$ \\
\hline Pretest & 30 & 15 & 50 & 29,33 \\
\hline Posttest & 30 & 50 & 80 & 65,33 \\
\hline
\end{tabular}

Berdasarkan hasil analisis data diperoleh effect size atau $E_{s}=0,71$ berdasarkan kategori yang ditentukan tingkat efektivitas maka pembelajaran menggunakan e-modul berbantuan software 3D Page Flip Proffesional pada Nilai Mutlak dikategorikan cukup efektif dan dapat digunakan dalam proses pembelajaran.

\section{Kesimpulan}

Kesimpulan yang diperoleh dari hasil penelitian dan pengembangan ini menghasilkan e-modul berbantuan software 3D Page Flip Proffesional. Berdasarkan hasil angket validasi 
diperolah rata-rata 3,52 oleh ahli materi, dan 3,50 oleh ahli media dengan kriteria valid. Sedangkan hasil uji coba respon mahasiswa diperoleh skor rata-rata 3,51 dengan kriteria sangak menarik. Ditinjau dari hasil uji effect size diperoleh ratarata 0,71 pada kategori sedang.

\section{Pustaka}

Abidin, Zainal, and Sikky El Walida, 2017, Pengembangan E-Modul Interaktif Berbasis Case (Creative, Active, Systematic, Effective) Sebagai Alternatif Media Pembelajaran Geometri Transformasi Untuk Mendukung Kemandirian Belajar Dan Kompetensi Mahasiswa, Seminar Nasional Matematika Dan Aplikasinya,

Aini, Asro Nur, Bambang Sri Anggoro, and Fredi Ganda Putra, 2018, Pengembangan Media Pembelajaran Matematika Pada Materi Transportasi Berbantuan Sparkol, UNION : Jurnal Pendidikan Matematika

Darmawan, D, 2012. Inovasi Pendidikan: Pendekatan Praktik Teknologi Multimedia dan Pembelajaran Online. Bandung: PT Remaja Rosdakarya.

JH, Taufik Solihudin, 2018, Pengembangan E-Modul Berbasis WEB Untuk
Meningkatkan Pencapaian

Kompetensi Pengetahuan

Fisika Pada Materi Listrik Statis

Dan Dinamis SMA, Jurnal

Wahana Pendidikan Fisika

Pujiriyanto, 2012, Teknologi Untuk Pengembangan Media dan Pembelajaran. Yogyakarta: UNY Press.

Saputro, Titon Agung, Kriswandani, and Novisita Ratu, 2018, Pengembangan Media Pembelajaran Mengunakan Aplikasi Construct 2 Pada Materi Aljabar Kelas VII, Jurnal Teori Dan Aplikasi Matematika

Shanley, L. (2016), Evaluating Longitudinal Mathematic Achievement Growth: Modeling and Measurement Considerations for Assessing Academic Progress,. Educational Researcher

Ula, Iin Rahmatul, and Abi Fadila, 2018, Pengembangan E-Modul Berbasis Learning Content Development System Pokok Bahasan Pola Bilangan SMP, Desimal: Jurnal Matematika

Yaqin, Ainul, and Rochmawati, 2017, Pengembangan Buku Saku Digital Berbasis Android Sebagai Pendukung Bahan Ajar Pada Materi Pph Pasal 21, Jurnal Pendidikan Akuntansi 